\title{
Determining The Diameter Of Erythrocyte By Means Of Manual Laser
}

\author{
Petar V. Vuca, Kikinda
}

Abstract: The article gives instructions on carrying out the school experiment with laser light.

Numerical value of the diameter of erythrocyte has been determined.

By applying this technique various erythrocyte morphology can be noticed. Size and shape of a blood cell are usually determined by means of a microscope. This method is quite boring, time-consuming and nonapplicable to a large number of specimens and cells. Relative to this method there is a simple and quick way of determining an average size and shape of a blood cell by means of laser light diffraction.

Blood specimens are taken from healthy people and patients suffering from various types of disease (cancer). The laser light diffraction method is very quick and easy to estimate an average size and shape blood cells. The new and sophisticated method that uses the laser tecnique has been developed for determining erythrocyte size, and the apparatus consists of a specimen (microscope slide), a laser and a screen where the radius/diameter of human erythrocytes is measured. The specimen, a drop of blood smeared on the microscope slide (a thin layer), is placed between the laser and the screen. He-Ne laser whose power is $\mathrm{P}=2 \mathrm{MW}$ is used for the diffraction. When passing through the blood specimen the laser beam forms an excellent diffraction image on the screen (picture 1). The slide with erythrocytes in a single layer has been provided by a hospital laboratory. When being placed on the optical bench between the laser and the screen, the slide ought to be turned towards the light source. The slide should be moved until a sharp and clear image of diffraction rings is formed, then the radius/diameter, $\mathbf{r}$, of the first (and the second) diffraction circle(s) is measured, as well as the distance from the laser to the screen $\mathbf{L}$. The diffraction angle is determined by $\tan \boldsymbol{\theta}=\mathbf{r} / \mathbf{L}$. The mean diameter of blood cells is determined by using the wave length of laser light $\lambda=\mathbf{6 3 2 , 2} \mathbf{n m}$.

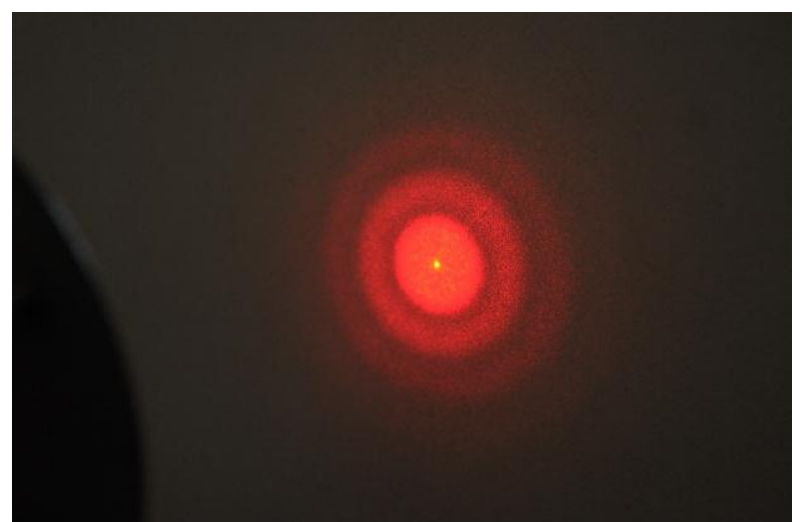

PICTURE 1: Diffraction on erythrocyte done in "Foto Sretenović" photo shop; photographed by Vladimir Sretenović

According to Rayleigh's expression (William Strutt) cell diameter $\mathbf{d}$ can be written as $\mathbf{d}=\mathbf{1 . 2 2} \lambda / \tan \boldsymbol{\theta}$. By replacing $\tan \boldsymbol{\theta}$ the equation for erythrocyte diameter $\mathbf{d}$ is obtained:

$$
\boldsymbol{d}=\boldsymbol{n} \cdot \lambda \cdot \boldsymbol{L} / \boldsymbol{r} \quad \boldsymbol{1}
$$

$\mathbf{r}$ - radius of the black circle, $\mathbf{L}$ - distance between the microscope slide and the screen (milimeter paper), $\lambda$ the laser light wavelength $(632,2 \mathrm{~nm}) ; \mathbf{n}=1.22 ; 2.23 ; 3.24$ is used for the rings.

We used a manual laser manufactured by MITT INFIZ, the power of which is $5 \mathrm{~mW}$ and the wavelength $: \lambda=$ 67o nm. (One must not look in the direction of the laser light.)

Applying the equation 1 the first diameter of an erythrocyte is calculated when the expression $\mathbf{d}_{\mathbf{1}}=1.22 \lambda \cdot \mathbf{L} / \mathbf{r}_{\mathbf{1}}$ $=9.31 \mu \mathrm{m}$ is used, for the second diameter of an erythrocyte $\mathrm{d}_{2}=2.23 \lambda \cdot \mathrm{L} / \mathrm{r}_{2}=8.81 \mu \mathrm{m}$, and the third diameter of an erythrocyte $-\mathrm{d}_{3}=3.24 \lambda \cdot \mathrm{L} / \mathrm{r}_{3}=\mathbf{9 . 2} \boldsymbol{\mu m}$.

The obtained results imply that the patient is ill. 


\section{Reference}

[1]. R. Krsnik. Suvremene ideje u metodici nastave fizike. Školska knjiga. Zagreb,2008 (R. Krsnik, Modern Ideas in Methodics of Teaching Physics, Školska knjiga, Zagreb,2008)

[2]. I. Janjić. Fizika II deo Novi Sad 1971 Janjić, Physics, Part 2, Novi Sad, 1971)

[3]. Kvant. Naučno-popularni fizičko-matematički žurnal. 1989 (Kvant, Popular Science Journal of Physics and Mathematics, 1989)

[4]. J. Simović, D. Koledin. Praktikum iz biofizike, Medicinska knjiga. Beograd-Zagreb, 1991

[5]. (J. Simović, D. Koledin, Book of Exercises in Biophysics, Medicinska knjiga, Belgrade-Zagreb, 1991)

[6]. C. Ramakrishna Rao, Kaleemed Jaleeli ${ }^{1}$, B.S. Bellubbi1 \&Adeel Ahmad ${ }^{1}$ 